\title{
Klasifikasi Predikat Tingkat Kelulusan Mahasiswa Program Studi Teknik Informatika dengan Menggunakan Algoritma C4.5 (Studi Kasus: STMIK Rosma Karawang)
}

\author{
Karya Suhada ${ }^{\mathrm{a} *}$, Anggi Eland a ${ }^{\mathrm{b}}$, Anwar Aziz $^{\mathrm{c}}$ \\ ${ }^{a, b, c}$ STMIK Rosma, Jl. Kertabumi No.62, Karawang 41311, Indonesia \\ ${ }^{a}$ Corresponding author: karya@rosma.ac.id
}

\begin{abstract}
The existence of technology will make it very easy for universities to produce information and facilitate all university activities related to data processing and report generation. The importance of predicting the graduation rate of students in higher education is to minimize the rate of students who do not graduate on time. STMIKRosma is one of the universities that graduate students every year. The purpose of this study was to analyze and predict student graduation in the Informatics Engineering study program class of 2012 - 2015 with data mining techniques using RapidMiner software in the application of the C4.5 algorithm and using the Cross-Industry Standard Process for Data Mining (CRIPS-DM) research method. The results of this study provide recommendations in the form of strategic information sources that are useful for universities, in this case STMIK Rosma, especially the study program on how to predict student graduation so that it can reduce the percentage of students who do not graduate on time.
\end{abstract}

Keywords : Classification, C4.5 Algorithm, CRISP-DM, Rapid Miner, Student Graduation

\begin{abstract}
Abstrak
Adanya teknologi akan sangat mudah bagi perguruan tinggi untuk menghasilkan informasi dan memudahkan segala aktivitas perguruan tinggi terkait dengan pengolahan data serta pembuatan laporan. Pentingnya memprediksi tingkat kelulusan mahasiswa dalam perguruan tinggi untuk dapat meminimalisir tingkat mahasiswa yang tidak lulus tepat waktu. STMIK Rosma merupakan salah satu perguruan tinggi yang banyak meluluskan mahasiswa setiap tahunnya. Tujuan penelitian ini adalah menganalisis serta memprediksi kelulusan mahasiswa pada program studi Teknik Informatika angkatan 2012 - 2015 dengan teknik data mining menggunakan sof tware RapidMiner dalam penerapan algoritma C4.5 dan menggunakan metode penelitian Cross Industry Standard for Data Mining (CRIPS-DM). Hasil dari penelitian ini memberikan rekomendasi berupa sumber informasi yang strategis beguna bagi perguruan tinggi dalam hal ini STMIK Rosma terutama program studi bagaimana memprediksi kelulusan mahasiswanya sehingga dapat mengurangi presentase mahasiswa yang tidak lulus tepat waktu.
\end{abstract}

Kata Kunci : Algoritma C4.5, CRISP-DM, Klasifikasi, Kelulusan Mahasiswa, Rapid Miner

\section{Pendahuluan}

Perkembangan zaman pada saat ini semakin berkembang pesat terutama teknologi informasi. Dengan adanya teknologi informasi dapat memudahkan pertukaran informasi, sehingga tempat, waktu dan jarak tidak lagi menjadi kendala. Jika dilihat dari beberapa sektor terutama sektor pendidikan, dituntut untuk menyesuaikan dengan perubahan zaman saat ini. Dengan adanya teknologi ini akan sangat mudah bagi perguruan tinggi untukmenghasilkan informasi dan memudahkan segala aktivitas perguruan tinggi terkait dengan pengolahan data serta pembuatan laporan. Laporan bisa berupa informasi yang dapat digunakan untuk kepentingan manajerial untuk menetukan langkah langkah apa 
saja yang harus dilakukan dimasa yang akan datang. Laporan bisa didapatkan dan dikumpulkan dalam kurun waktu tertentu sesuai dengan kebutuhan biasanya sebagai perbandingan yaitu setiap lima tahun kebelakang yang nantinya bisa disimpulkan oleh pihak yang berkepentingan dalam hal ini STMIK Rosma.

Sekolah Tinggi Manajemen Informatika dan Komputer (STMIK) Rosma merupakan perguruan tinggi satu satunya diKarawang yang memiliki 4 program studi yang meluluskan banyak mahasiswa pada setiap tahunnya, salah satunya pada program studi Teknik Informatika. STMIK Rosma ini mengalami kesulitan dalam memprediksi kelulusan mahasiswa/I untuk itu dibutuhkannya suatu sistem yang dapat digunkan untuk memprediksi kelulusan mahasiswa. Jika kelulusan mahasiswa tidak diketahui maka pihak manajemen akan menerapkan sutu kebijakan bagaimana untuk meminimalisir jumlah mahasiswa yang tidak tepat waktu kelulusannya sesuai dengan masa studinya. Dengan adanya data mining ini memiliki tujuan adalah dapat memberikan informasi yang beguna bagi manajemen dan dapat membantu pihak tertentu yang membutuhkannya.

Adapun beberapa penelitian terdahulu yang melatar belakangi penulisan artikel ini adalah penelitian yang dilakukan oleh (Luvia et al., 2016) yang mengklasifikasi predikat keberhasilan kahasiswa di Amik Tunas Bangsa menggunakan Algoritma C4.5, (Sitorus et al., 2019) yang melakukan penerapan Klasifikasi C4.5 dalam meningkatkan sistem pmbelajaran mahasiswa, (Fadillah, 2015) memprediksi kelulusan studi mahasiswa menempuh mata muliah menggunakan metode CRISP-DMuntuk (Studi Kasus Universitas XYZ), dan penelitian yang dilakukan oleh (Rahayu et al., 2021) yang mengklasifikasikan ketepatan waktu kelulusan mahasiswa dengan metode naïve bayes.

Berdasarkan uraian diatas maka penulis merasa tertarik untuk membuat sebuah analisis prediksi kelulusan mahasiswa dengan menggunakan Algoritma C4.5 pada akhirnya bisa dimanfaatkan oleh pihak kampus untuk mengatasi permasalahan yang ada sehingga dengan adanya informasi tersebut perguruan tinggi dapat bersaing dengan yang lainnya bahkan semakin maju serta diharapkan dapat menjadi sebuah inof rmasi yang sangat penting sehingga bisa meningkatkan kualitas mahasiswa STMIK Rosma.

\section{Tinjauan Pustaka}

\subsection{Klasifikasi}

Klasifikasi adalah kegiatan dalam mengekstrak dan memprediksi kategori untuk masing-masing data. Klasifikasi melakukan pencarian model yang dapat membedakan kelas data dengan tujuan agar model dapat digunakan untuk memprediksi kelas dari suatu obyek yang kelasnya belum diketahui (Nasrullah, 2018). Sedangkan menurut (Sartika \& Sensuse, 2017) klasifikasi merupakan salah satu teknik data mining yang digunakan untuk membangun suatu model dari sampel data yang belum sejenis. Karena menggunakan sekumpulan data untuk dianalis terlebih dahulu dan pola yang didapatkan dari hasil analisis digunakan untuk pengklasifikasian data uji, teknik klasifikasi ini termasuk dalam supervises learning. Proses klasifikasi data terdiri dari pembelajaran dan klasifikasi.

\subsection{Predikat Kelulusan}

Perguruan tinggi memiliki kewajiban dalam mengontorl mahasiswanya untuk menghasilkan lulusan yang berkualitas. Lulusan yang berkualitas dapat dilihat dari indeks prestasi dan lamanya studi yang menghasilkan predikat kelulusan. Adanya beberapa faktor tertentu yang mempengaruhi predikat kelulusan (Imaslihkah et al., 2013). Menurut (Rusdiana \& Rosmiati, 2016) penentuan predikan mahasisawa dapat dilakukan dengan mengkelompokan data yang didapat berdasarkan jumlah beban studi yang telah ditempuk, IPK yang didapatkan mahasiswa, dan keterangan kelulusan skripsi. Predikat kelulusan dapat diterima oleh mahasiswa jika memenuhi syarat antara lain :

a. Indeks prestasi kumulatif menunjukn paling sedikit yaitu nilai minimal yang telah ditetapkan oleh kampus.

b. Jumlah SKS yang telah ditentukan.

c. Lulus ujian skripsi.

Persyaratan diatas tentunya dapat berbeda disetiap perguruan tinggi. Tentunya mahasiswa dapat dinyatakan lulus apabila memenuhi syarat yang telah ditentukan oleh masing-masing perguruan tinggi tersebut.

\subsection{Data Mining}


Definisi data mining menurut (Permata et al., 2012) menyatakan bahwa data mining berasal dari berbagai ilmu pengetahuan, yang meliputi machine learning atau pattern recognatio, statistik atau kecerdasan buatas, dan sistem basis data. Data mining adalah proses yang menggunakan teknik statistik, matematika, kecerdasan buatan, dan machine learning untuk mengekstraksi dan mengidentifikasi informasi yang bermanfaat dan pengetahuan yang terkait dari berbagai database besar. Data mining merupakan serangkaian proses untuk menggali nilai tambah dari suatu kumpulan data berupa pengetahuan yang selama ini tidak diketahui secara manual (Purnia \& Warnilah, 2017).

\subsection{Algpritma C4.5}

Algoritma $\mathrm{C} 4.5$ adalah metode pohon keputusan dimana fakta yang sangat besar menjadi pohon keputusan yang merepresentasikan aturan. Aturan dapat dengan mudah dipahami dengan bahasa alami. Pada algoritma C4.5 pohon keputusan yang dibentuk berdasarkan kriteria-kriteria pembentuk keputisan. Dalam algoritma C4.5 ini terdapat 2 elemen yang harus dipahami yaitu Entropy dan Gain (Wajhillah \& Yulianti, 2017).

Menurut (Honesqi, 2017) menyatakan bahwa algoritma C4.5 merupakan algoritma klasifikasi data bertipe pohon keputusan. Pohon keputusan algoritma $\mathrm{C} 4.5$ dibangun dengan beberapa tahapan atau langkah yaitu sebagai berikut:

a. Pemilihan atribut sebagai akar.

b. Membuat cabang untuk tiap-tiap nilai.

c. Membagi kasus dalam cabang.

Tahap-tahap ini akan diulangi untuk setiap cabang sampai semua kasus pada cabang memiliki kelas yang sama. Dari penyelesaian pohon keputusan maka akan didapatkan beberapa rule suatu kasus. Algoritma C.45 memiliki kelebihan yaitu mudah dimengerti, fleksibel, dan menarik karena hasil yang didapatkan dapat divisualisasikan dalam bentuk gambar sebagai pohon keputusan (Honesqi, 2017).

\subsection{Rapid Miner}

RapidMiner adalah platform perangkat lunak data ilmu pengetahuan yang dikembangkan oleh perusahaan dengan nama yang sama, yang menyediakan lingkungan terpadu untuk pembelajaran mesin (machine learning), pembelajaran mendalam (deep learning), penambangan teks (text mining), dan analisis prediktif (predictive analytics). Aplikasi ini digunakan untuk aplikasi bisnis dan komersial serta untuk penelitian, pendidikan, pelatihan, pembuatan prototype dengan cepat, dan pengembangan aplikasi serta mendukung semua langkah proses pembelajaran mesin termasuk persiapan data, visualisasi hasil, validasi dan pengoptimalan. RapidMiner dikembangkan dengan model open core (Muhammad et al., 2018).

\section{Metode}

Penelitiann ini menyelesaikan masalah dengan menggunakan pendekatan kuantitatif dengan jenis pendekatan eksperimen. Alur pada penelitian ini, disesuaikan dengan tahapan pada metode CRISP-DM. CRISP-DM merupakan metode yang menggunakan model proses pengembangan data yang banyak digunakan para ahli untuk memecahkan masalah. Proses penelitian ini mengacu pada enam tahap CRISP-DM yaitu pemahaman bisnis, pemahaman data, persiapan data, pemodelan, evaluasi dan penyebaran (Astuti et al., 2019).

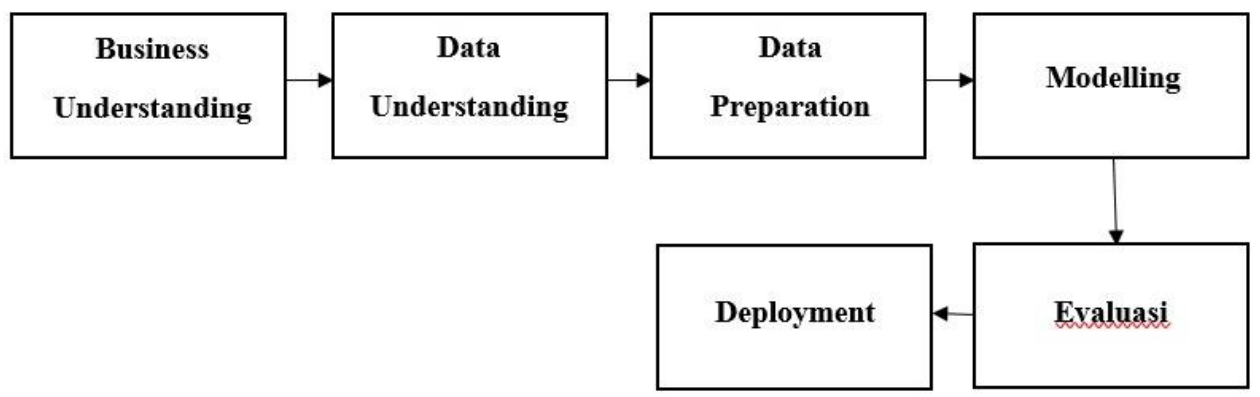

Gambar 1. tahap CRISP-DM

\section{a. Business Understanding}


Busines understanding adalah awal daei proses CRISP-DM yang merupakan pemahaman terhadap tujuan bisnis, penelitian situasi dan menerjemahkan tujuan bisnis kedalam tujuan data mining. Dalam penelitian ini tentunya membutuhkan pengetahuan untuk mendapatkan data yang mendukung proses klasifikasi predikat kelulusan mahasiswa.

b. Data Understanding

Data understanding ini dilakukan proses pengumpulan data mahasiswa dan melakukan analisis data dan evaluasi kualitas data untuk mengenali data lebih lanjut dan mencari pengetahuan awal. Sumber data yang digunakan dalam penelitian ini adalah data mahasiswa program studi teknik informatika STMIK Rosma Karawang.

c. Data Preparation

Data preparation ini dilakukan prosesn penyusunan dataset final atau datasety ang nantinya akan dijadikan inputan kedalam modelling data mining. Tahapan dalam data preparation yaitu pemilihan data, transformasi data, dan pembersihan data.

d. Modeling

Modeling ini dilakukan sesuai teknik pemodelan yang dipilih yang nantinya akan diterapkan pada dataset yang sudah disiapkan untuk mengatasi kebutuhan bisnis yang sesuai. Teknik pemodelan dalam penelitian ini menggunakan teknik klasifikasi, dengan menggunakan algoritma C4.5. Tools yang digunakan dalam pemodelan ini yaitu RapidMiner.

e. Evaluasi

Evaluasi ini menguji model yang sudah dibuat dan dilakukan evaluasi keakuratan dan generalitasnya. Tahapan ini dilakukan untuk mengukur sejauh mana model yang telah dipilih memenuhi sasaran bisnis dan bila demikiam, apakah perlu lebih banyak model untuk dibuat lagi.

f. Deployment

Deployment merupakan penyusunan laporan atau presebtasi dari modelling serta evaluation pada proses data mining. Hasil penelitian ini bisa digunakan untuk informasi tingkat kelulusan mahasiswa sebagai bahan kajian bagi perguruan tinggi. dengan mengetahui informasi tingkat kelulusan dapat memberikan kemudahan bagi staff dalam melakukan pengolaan mahasiswa. Dan juga dapat memberikan informasi kepada mahasiswa agar dapat lulus dengan tepat waktu.

\section{Hasil dan Pembahasan}

\subsection{Business Understanding (Pemahaman Bisnis)}

Tahapan pemahaman bisnis ini merupakan pemahaman dari kegiatan penelitian data mining yang akan diakukan.Pemahamana bisnis ini dimulai dari tujuan penelitian dan pemaparan masalah yang ditemukan.Pada tahapan ini terdapat empat fase yaitu determine business objective, assess situation, determine data mining goals dan produce project plan.

\section{a. Determine Business Objective}

Berdasarkan penjelasann yang sudah dijelaskan pada latar belakang sebelumnya, penelitian ini memiliki tujuan yaitu menganalisis prediksi terhadap kelulusan mahasiswa teknik informatika STMIK Rosma Karawang dengan menggunakan metode C4.5. Terdapat dua parameter dalam dalam melakukan prediksi ketepatan kelulusan seorang mahasiswa yaitu lulus tepat waktu dan lulus terlambat. Hal ini didasari dari pengaruh kelulusan mahasiswa tersebut yang dimana dapat dipengaruhi dari jenis kelamin, asal daerah, SKS yang sudah ditempuh, IPK, predikat kelulusan.

b. Assess Situation

Seperti informasi yang diketahui bahwa mahasiswa teknik informatika STMIK Rosma Karawang pada angkatan tahun 2012, 2013, 2014, 2015 dan 2016 memiliki jumlah mahasiswa dengan lulus tepat waktu yang cukup kecil. Diketahui bahwa tahun 2012 dari total mahasiswa yang masuk pada tahun tersebut sebanyak 45 mahasiswa dan hanya 40\% mahasiswa y ang dinyatakan lulus tepat waktu. Pada tahun 2013 juga terdapat total mahasiswa yang masuk pada tahun tersebut sebanyak 63 mahasiswa dan hanya $39 \%$ mahasiswa yang dinyatakan lulus tepat waktu. Tahun 2014 terdapat total mahasiswa yang masuk pada tahun tersebut sebanyak 55 mahasiswa dan 55\% mahasiswa yang dinyatakan lulus tepat waktu. Tahun 2015 terdapat 95 mahasiswa yang mendaftar dan hanya $23 \%$ mahasiswa yang lulus tepat waktu. Dan pada tahun 2016 terdapat mahasiswa yang lulus sebanyak 40\% dari total mahasiswa sebanyak 61 mahasiswa. 
c. Determine Data Mining Goals

Tujuan utama penelitian ini adalah untuk melakukan analisis prediksi kelulusan mahasiswa teknik informatika STMIK Rosma Karawang dengan menggunakan metode C4.5 dan mengevaluasi kinerja dari model. Setelah itu akan diperoleh pengetahuan baru dari data mahasiswa yang sudah diolah. Kemudian hasil dari prediksi yang telah dilakukan menggunakan metode C4.5 dapa dimanfaatkan pihak pergutuan tingggi untuk meningkatkan kualitas mahasiswa teknik informatika STMIK Rosma Karawang.

d. Produce Project Plan

Rencana penelitian yang akan dilakukan meliputi dari pengumpulan data mahasiswa teknik informatika STMIK Rosma Karawang dari angkatan tahun 2012, 2013, 2014, 2015, hingga 2016 dengan atribut yang digunakan adalah jenis kelamin, asal daerah, SKS yang sudah ditempuh, IPK, predikat kelulusan. Dengan atribut yang sudah ada tersebut maka dilakukan pemodelan dengan menggunakan metode $\mathrm{C} 4.5$ dan memanfaatkan cross validation untuk mengukur validitas model klasifikasi dengan menggunakan tools RapidMiner.

\subsection{Data Understanding (Pemahaman Data)}

Pada tahapan ini dilakukan pengumpulan data akademik mahasiswa pada jurusan teknik informatika STMIK Rosma Karawang berupa nomor ijazah, NIM, nama, Jenis kelamin, asal daerah, tanggal lahir, jumlah SKS, IPK, predikat, dan lama studi. Kemudian data tersebut akan dipelajari dan dipahami untuk mengetahui data apa saja yang dapat dimanfaatkan dari data yang telah diperoleh dalam melakukan analisis prediksi kelulusan mahasiswa nantinya. Pada data understanding terdapat empat fase yaitu collect initial data, describe data. Explore data dan verify quality.

a. Collect Initial Data

Tahapan ini dilakukan pengumpulan data awal di mana data diperoleh dari tata usaha STMIK Rosma Karawang.

Tabel 1. Data Mahasiswa Teknik Informatika STMIK Rosma Karawang

\begin{tabular}{|c|c|c|c|c|c|c|c|c|c|c|}
\hline NO & Nomor Seri ljazah & NIM & Nama & Jenis Kelamin & Asal Daerah & Tanggal Lahir & Jumlah SKS & IPK & Predikat & Lama Studi \\
\hline 1 & $2014 / 1$ & 201201 & Mahasiwa01 & Prempuan & Karawang & 27 September 1990 & 145 & 2,83 & Memuaskan & 4 \\
\hline 2 & $20413 / 1$ & 201202 & Mahasiwa02 & Laki-Laki & Luar karawang & 22 Oktober 1991 & 145 & 3,19 & Sangat Memuaskan & 4 \\
\hline 3 & $20513 / 1$ & 201203 & Mahasiswa03 & Laki-Laki & Karawang & 13 Juni 1990 & 145 & 2,81 & Memuaskan & 4 \\
\hline 4 & $20513 / 1$ & 201204 & mahasiswa04 & Laki-Laki & Karawang & 26 Februari 1995 & 145 & 2,97 & Memuaskan & 4 \\
\hline 5 & $20613 / 1$ & 201205 & Mahasiswa05 & Laki-Laki & Karawang & 31 Desember 1993 & 145 & 2,98 & Memuaskan & 4 \\
\hline 6 & $10013 / 1$ & 201206 & Mahasiswa06 & Prempuan & Karawang & 03 Maret 1992 & 145 & 3,67 & Cumlaude & 4 \\
\hline 7 & $20013 / 1$ & 201207 & Mahasiswa07 & Laki-Laki & Karawang & 12 Juni 1993 & 145 & 2,80 & Memuaskan & 4 \\
\hline 8 & $10013 / 1$ & 201208 & Mahasiswa08 & Laki-Laki & Karawang & 09 September 1984 & 145 & 3,57 & Cumlaude & 4 \\
\hline 9 & $40013 / 1$ & 201209 & Mahasiswa09 & Prempuan & Karawang & 16 Januari 1996 & 145 & 3,03 & Sangat Memuaskan & 4 \\
\hline 10 & $20013 / 1$ & 201210 & Mahasiswa10 & Laki-Laki & Karawang & 30 Maret 1996 & 145 & 3,63 & Sangat Memuaskan & 4 \\
\hline 11 & $90013 / 1$ & 201211 & Mahasiswa11 & Laki-Laki & Karawang & 19 September 1996 & 145 & 2,98 & Memuaskan & 4 \\
\hline 12 & $20013 / 1$ & 201212 & Mahasiswa12 & Laki-Laki & Luar karawang & 10 Maret 1995 & 145 & 3,17 & Sangat Memuaskan & 4 \\
\hline 13 & $20213 / 1$ & 201213 & Mahasiswa13 & Laki-Laki & Luar karawang & 21 Juli 1993 & 145 & 3,18 & Sangat Memuaskan & 4 \\
\hline 14 & 20113/1 & 201214 & Mahasiswa14 & Laki-Laki & Luar karawang & 16 Mei 1996 & 145 & 2,88 & Memuaskan & 4 \\
\hline 15 & 20113/I & 201215 & Mahasiswa15 & Prempuan & Luar karawang & 20 Februari 1993 & 145 & 2,88 & Memuaskan & 4 \\
\hline 16 & 20113/I & 201216 & Mahasiswa16 & Laki-Laki & Luar karawang & 10 Juli 1991 & 145 & 3,01 & Sangat Memuaskan & 4 \\
\hline 17 & 20113/I & 201217 & Mahasiswa17 & Laki-Laki & Karawang & 10 Januari 1998 & 145 & 3,01 & Sangat Memuaskan & 4 \\
\hline 18 & 20113/I & 201218 & Mahasiswa18 & Laki-Laki & Luar karawang & 12 Januari 1997 & 145 & 3,50 & Sangat Memuaskan & 4 \\
\hline 19 & 20113/I & 201219 & Mahasiswa19 & Laki-Laki & Luar karawang & 13 Januari 1997 & 145 & 3,60 & Cumlaude & 2 \\
\hline 20 & 20113/I & 201220 & Mahasiswa20 & Prempuan & Karawang & 14 Januari 1997 & 145 & 3,12 & Sangat Memuaskan & 5 \\
\hline
\end{tabular}

Tabel 1 merupakan data diri mahasiswa teknik informatika STMIK Rosma Karawang. Data yang diperoleh adalah data mahasiswa angkatan 2012, 2013, 2014, 2015, dan juga 2016 yang telah lulus. Dari data tersebut nantinya dapat ditentukan mana saja mahasiswa yang termasuk kedalamkategori mahasiswa dengan lulus tepat waktu dan terlambat. Jumlah data mahasiswa yang lulus diperoleh sebanyak 146 dengan 10 atribut.

\section{a. Describe Data}

Setelah didapatkan data awal, selanjutnya adalah mendeskripsikan data yang telah didapatkan sebelumnya. Tujuan ini dilakukan untuk mencari sedikit informasi mengenai atribut dari data yang 
telah didapat dan memahami data yang akan diolah dalam melakukan prediksi ketepatan kelulusan mahasiswa. Dibawah ini pada tabel 2 merupakan deskripsi atribut semua data yang telah diperoleh sebelumnya.

Tabel 2. Deskripsi Atribut Data

\begin{tabular}{clll}
\hline No & \multicolumn{1}{c}{ Atribut } & \multicolumn{1}{c}{ Jenis } & \multicolumn{1}{c}{ Keterangan } \\
\hline 1 & Nomor Ijazah & Polynominal & Nomor ijazah mahasiswa \\
\hline 2 & NIM & Polynominal & Nomor Induk Mahasiswa \\
\hline 3 & Nama & Polynominal & Nama Mahasiswa \\
\hline 4 & Jenis Kelamin & Binominal & Jenis Kelamin Mahasiswa \\
\hline 5 & Asal Daerah & Binominal & Asal Daerah Mahasiswa \\
\hline 6 & Tanggal Lahir & Polynominal & Tanggal Lahir Mahasiswa \\
\hline 7 & Jumlah SKS & Integer & Jumlah SKS yang telah ditempuh \\
\hline 8 & IPK & Polynominal & Indeks Prestasi Kumulatif (IPK) mahasiswa \\
\hline 9 & Predikat & Polynominal & Predikat Mahasiswa \\
\hline 10 & Lama Studi & Integer & Lamanya Studi Mahasiswa \\
\hline
\end{tabular}

b. Explore Data

Setelah dilakukannya deskripsi data, fase yang selanjutnya adalah melakukan eksplorasi terhadap data, dan kemudian akan diberikan deskripsi mengenai isi data dari setiap atribut pada data yang diperoleh.

Tabel 3. Eksplorasi Data

\begin{tabular}{|c|c|c|c|}
\hline No & Atribut & Keterangan & Eksplorasi Data \\
\hline 1 & Nomor Ijazah & $\begin{array}{l}\text { Nomor ijazah mahasiswa angkatan } \\
2012,2013,2014,2015 \text { dan } 2016\end{array}$ & $\begin{array}{l}\text { Jumlah nomor ijazah mahasiswa: } \\
\text { - Angkatan Tahun } 2012=26 \\
\text { - Angkatan Tahun } 2013=31 \\
\text { - Angkatan Tahun } 2014=33 \\
\text { - Angkatan Tahun } 2015=31 \\
\text { - Angkatan Tahun } 2016=25 \\
\text { Total data keseluruhan adalah } 146 .\end{array}$ \\
\hline 2 & NIM & $\begin{array}{l}\text { Nomor Induk Mahasiswa (NIM) } \\
\text { dari tahun angkatan 2012, 2013, } \\
2014,2015 \text { dan } 2016\end{array}$ & $\begin{array}{l}\text { Jumlah nomor induk mahasiswa: } \\
\text { - Angkatan Tahun } 2012=26 \\
\text { - Angkatan Tahun } 2013=31 \\
\text { - Angkatan Tahun } 2014=33 \\
\text { - Angkatan Tahun } 2015=31 \\
\text { - Angkatan Tahun } 2016=25 \\
\text { Total data keseluruhan adalah } 146 .\end{array}$ \\
\hline 3 & Nama & 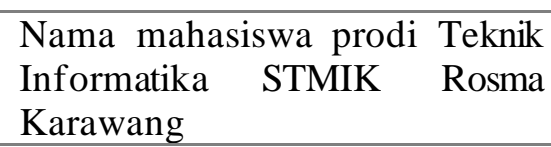 & Total data keseluruhan adalah 146. \\
\hline 4 & Jenis Kelamin & $\begin{array}{l}\text { Jenis kelamin mahasiswa } \\
\text { berisikan : } \\
\text { - Laki-Laki } \\
\text { - Perempuan }\end{array}$ & $\begin{array}{l}\text { Jumlah jenis kelamin mahasiswa } \\
\text { - Laki }- \text { Laki }=108 \\
\text { - Perempuan }=38 \\
\text { Total data keseluruhan adalah } 146\end{array}$ \\
\hline 5 & Asal Daerah & $\begin{array}{l}\text { Asaldaerah mahasiswa berisi : } \\
\text { - Karawang } \\
\text { - Luar Karawang }\end{array}$ & $\begin{array}{l}\text { Jumlah asal daerah mahasiswa : } \\
\text { - Karawang }=54 \\
\text { - Luar Karawang }=73 \\
\text { Total data keseluruhan adalah } 127\end{array}$ \\
\hline 6 & Tanggal Lahir & Tanggal Lahir Mahasiswa & Total data keseluruhan adalah 127 \\
\hline 7 & Jumlah SKS & $\begin{array}{l}\text { Jumlah Satuan Kredit Semester } \\
\text { (SKS) yang telah ditempuh }\end{array}$ & $\begin{array}{l}\text { Jumlah SKS : } \\
\text { Min }=64 \\
\text { Max }=145\end{array}$ \\
\hline
\end{tabular}




\begin{tabular}{|c|c|c|c|}
\hline No & Atribut & Keterangan & Eksplorasi Data \\
\hline 8 & IPK & $\begin{array}{l}\text { Indeks Prestasi Kumulatif (IPK) } \\
\text { mahasiswa pada angkatan } 2012 \\
\text { dampai } 2016\end{array}$ & $\begin{array}{l}\text { IPK mahasiswa angkatan 2012-2016: } \\
\text { Min }=2.54 \\
\text { Max }=3.76 \\
\text { Mean }=3.10\end{array}$ \\
\hline 9 & Predikat & $\begin{array}{l}\text { Predikat kelulusan mahasiswa dari } \\
\text { angkatan } 2012 \text { - } 2016\end{array}$ & $\begin{array}{l}\text { Jumlah predikat kelulusan mahasiswa } \\
: \\
\text { - Cumlaude }=8 \\
\text { - Sangat Memuaskan }=91 \\
\text { - Memuaskan }=47 \\
\text { Total data keseluruhan adalah } 146 .\end{array}$ \\
\hline 10 & Lama Studi & $\begin{array}{l}\text { Lamanya Studi Mahasiswa yang } \\
\text { telah lulus dari angkatan } 2012- \\
2016\end{array}$ & $\begin{array}{l}\text { Jumlah studi mahasiswa: } \\
\text { Min = } 2 \text { Tahun } \\
\text { Max =7 Tahun }\end{array}$ \\
\hline
\end{tabular}

\section{c. Verify Data Quality}

Fase verifikasi kualitas data ini akan melakukan pengecekan seperti missing value, data yang tidak konsisten, data noise atau data outlier. Dimana pengecekan ini bertujuan untuk mengetahui seberapa baik kualitas data yng telah didapatkan sebelumnya.

Dapat dilihat pada gambar 4 bahwa data yang telah diperoleh dari tata usaha terny ata masih terdapat missing value di beberapa asal daerah dan tanggal lahir. Dapat dilihat data yang mengandung missing value ialah baris kosong pada kolom asal daerah dan tanggal lahir.

Tabel 4. Missing Value Data

\begin{tabular}{|c|c|c|c|c|c|c|c|c|c|c|}
\hline 27 & Nomor Seri ljazah & NIM & Nama & Jenis Kela & Asal Daer & Tanggal Lahir & Jumlah SKS & IPK & Predikat L & Lama Studi \\
\hline 28 & 20313/I & 201301 & Mahasiw: & Prempuar & Karawang & 27 September 1990 & 145 & 2,83 & Memuask & 4 \\
\hline 29 & $20413 / 1$ & 201302 & Mahasiw: & Laki-Laki & Luar karav & 22 Oktober 1991 & 145 & 3,19 & Sangat $\mathrm{ME}$ & 4 \\
\hline 30 & $20513 / 1$ & 201304 & Mahasisy & Laki-Laki & Karawang & 13 Juni 1990 & 145 & 2,81 & Memuask & 4 \\
\hline 31 & $20513 / 1$ & 201305 & mahasisy & Laki-Laki & Karawang & 26 Februari 1995 & 145 & 2,97 & Memuask & 4 \\
\hline 32 & 20613/I & 201402 & Mahasisy & Laki-Laki & Karawang & 31 Desember 1993 & 145 & 2,98 & Memuask & 4 \\
\hline 33 & $10013 / 1$ & 201306 & Mahasisy & Prempuar & Karawang & 03 Maret 1992 & 145 & 2,79 & Memuask & 3 \\
\hline 34 & $20013 / 1$ & 201306 & Mahasisy & Laki-Laki & Karawang & 12 Juni 1993 & 145 & 2,80 & Memuask & 5 \\
\hline 35 & $10013 / 1$ & 201306 & Mahasisy & Laki-Laki & Karawang & 09 September 1984 & 145 & 3,57 & Sangat $\mathrm{M}$ & 5 \\
\hline 36 & $40013 / 1$ & 201306 & Mahasisy & Prempuar & Karawang & 16 Januari 1996 & 145 & 3,03 & Sangat $\mathrm{ME}$ & 5 \\
\hline 37 & $20013 / 1$ & 201306 & Mahasisy & Laki-Laki & Karawang & 30 Maret 1996 & 145 & 3,63 & Sangat $\mathrm{ME}$ & 5 \\
\hline 38 & $90013 / 1$ & 201403 & Mahasisy & Laki-Laki & Karawang & 19 September 1996 & 145 & 2,98 & Memuask & 4 \\
\hline 39 & $20013 / 1$ & 201404 & Mahasisy & Laki-Laki & Luar karay & 10 Maret 1995 & 145 & 3,17 & Sangat $\mathrm{ME}$ & 4 \\
\hline 40 & 20213/I & 201405 & Mahasisy & Laki-Laki & Luar karav & 21 Juli 1993 & 145 & 3,18 & Sangat $\mathrm{ME}$ & 4 \\
\hline 41 & 20113/I & 201406 & Mahasisy & Laki-Laki & Luar karav & 16 Mei 1996 & 145 & 2,88 & Memuask & 4 \\
\hline 42 & $20113 / 1$ & 201407 & Mahasisy & Prempuar & Luar karay & 20 Februari 1993 & 145 & 2,88 & Memuask & 4 \\
\hline 43 & $20101 / 1$ & 201408 & Mahasisy & Laki-Laki & Luar karav & 10 Juli 1991 & 145 & 3,01 & Sangat $\mathrm{ME}$ & 4 \\
\hline
\end{tabular}

\subsection{Data Preparation (Persiapan Data)}

Setelah melalui tahapan pengumpulan data awal dan pemahaman data yang telah diperoleh. Tahapan selanjutnya yaitu melakukan persiapan data sebelum data diproses menggunakan teknik data mining. Persiapan data dilakukan untuk mengubah data mentah menjadi data yang siap digunakan sehingga ketika proses predisi kelulusan mahasiswa dapat berjalan dengan lancar. pada tahapan ini terdapat lima fase yang harus dilakukan yaitu selet data, clean data, construct data, dan format data.

a. Secelect Data

Dari data awal yang telah dikumpulkan, dipilih beberapa atribut yang nantiny a atribut tersebut dianggap sebagai atribut yang berpengaruh terhadap waktu kelulusan mahasiswa. Atribut yang dipilih yaitu NIM, nama, jenis kelamin, asal daerah, tanggal lahir, jumlah sks, IPK, predikat, lamastudi, dan stauts kelulusan.

Tabel 5. Atribut Data Terpilih 


\begin{tabular}{ll}
\hline No & \multicolumn{1}{c}{ Atribut } \\
\hline $\mathbf{1}$ & NIM \\
\hline $\mathbf{2}$ & Nama \\
\hline $\mathbf{3}$ & Jenis Kelamin \\
\hline $\mathbf{4}$ & Asal Daerah \\
\hline $\mathbf{5}$ & Jumlah SKS \\
\hline $\mathbf{6}$ & IPK \\
\hline $\mathbf{7}$ & Predikat \\
\hline $\mathbf{8}$ & Lama Studi \\
\hline $\mathbf{9}$ & Status Kelulusan \\
\hline
\end{tabular}

Atribut NIM, nama, dan lama studi hanya digunakan sebagai identitas data saja. Sedangkanjenis kelamin, asal daerah, jumlah sks, IPK, predikat, dan lama studi yang akan diproses menggunakan teknik data mining dengan metode C4.5. Data yang dibutuhkan dalam melakukan prediksi kelulus ini ialah data mahasiswa angkatan 2012, 2013, 2014, 2015, dan 2016 yang telah lulus. Pada atribut status kelulusan akan berisikan dua buah nilai yaitu "Tepat Waktu" dan "Terlambat". Dua nilai tersebut diambil dari hasil tranformasi lama studi dan tahun lulus.

\section{b. Clean Data}

Fase ini dilakukan untuk memastikan bahwa data yang digunakan sudah benar-benar memiliki kualitas yang baik, sehingga ketika melakukan prediksi mendapatkan hasil yang terbaik. Seperti yang telah diketahui data yang telah dikumpulkan memiliki beberapa missing value yang dapat dilihat pada gambar 4.2. Oleh karena itu pada tahapan ini data akan diolah untuk menangani data yang terdapat missing value. Salah satu cara yang dapat digunakan untuk mengatasi data yang terda pat missing value ialah menghapus data yang mengandung missing value pada dataset yang ada. Dibawah ini adalah gambaran data mahasiswa yang telah diurutkan dari mahasiswa angkatan 2012, 2013, 2014, 2015, dan 2016 yang telah diperoleh dan megandung missing value.

Tabel 6. Missing Value Data Mahasiswa 2012-2016

\begin{tabular}{|c|c|c|c|c|c|c|c|}
\hline NIM & Nama & Jenis kelamin & Asal Daerah & Jumlah sks & IPK & Predikat & Lama Studi \\
\hline 201401 & Mahasiswa01 & Laki-Laki & $?$ & 145 & 3,15 & Sangat Memuaskan & 4 \\
\hline 201402 & Mahasiswa02 & Laki-Laki & $?$ & 145 & 2,97 & Memuaskan & 4 \\
\hline 201403 & Mahasiswa03 & Perempuan & $?$ & 145 & 2,97 & Memuaskan & 3 \\
\hline 201502 & Mahasiswa04 & Laki-Laki & $?$ & 145 & 3,12 & Sangat Memuaskan & 4 \\
\hline 201404 & Mahasiswa05 & Laki-Laki & $?$ & 145 & 2,92 & Memuaskan & 4 \\
\hline 201405 & Mahasiswa06 & Perempuan & $?$ & 145 & 2,92 & Memuaskan & 5 \\
\hline 201301 & Mahasiswa07 & Laki-Laki & $?$ & 145 & 2,94 & Memuaskan & 4 \\
\hline 201406 & Mahasiswa08 & Laki-Laki & $?$ & 145 & 2,96 & Memuaskan & 4 \\
\hline 201408 & Mahasiswa09 & Laki-Laki & $?$ & 145 & 3,15 & Sangat Memuaskan & 4 \\
\hline 201409 & Mahasiswa10 & Laki-Laki & $?$ & 145 & 2,96 & Memuaskan & 4 \\
\hline 201410 & Mahasiswa11 & Laki-Laki & $?$ & 145 & 3,19 & Sangat Memuaskan & 4 \\
\hline 201411 & Mahasiswa12 & Laki-Laki & $?$ & 145 & 3,00 & Sangat Memuaskan & 5 \\
\hline 201412 & Mahasiswa13 & Laki-Laki & $?$ & 145 & 2,92 & Memuaskan & 4 \\
\hline 201313 & Mahasiswa14 & Laki-Laki & $?$ & 145 & 3,17 & Sangat Memuaskan & 4 \\
\hline
\end{tabular}

Tabel 6 diatas merupakan data mahasiswa angkatan 2012-2016 yang mengandung missing value. Missing value dapat dilihatpada baris yang bersikan tanda tanya. Untuk mengatasi hal tersebut, maka akan dilakukan penghapusan data yang mengandung missing value. Total keseluruhan data sebanyak 146 data, sebanyak 19 data termasuk missing value dihilangkan, sehingga hanya terdapat 127 data yang akan diproses ke tahapan selanjutnya.

Gambar 7. Hasil Cleaning Data Mahasiswa 2012-2016 


\begin{tabular}{|r|l|l|l|l|l|l|c|}
\hline \multicolumn{2}{|l|}{ NIM } & Nama & Jenis Kelamin & Asal Daerah & Jumlah Sk IPK & Predikat & Lama Studi \\
\hline 201201 & Mahasiswa01 & Laki-Laki & Karawang & 145 & 2,79 & Memuaskan & 4 \\
\hline 201202 & Mahasiswa02 & Laki-Laki & Luar Karawang & 145 & 3,23 & Sangat Memuaskan & 4 \\
\hline 201205 & Mahasiswa03 & Perempuan & Luar Karawang & 145 & 3,12 & Sangat Memuaskan & 4 \\
\hline 201206 & Mahasiswa04 & Laki-Laki & Luar Karawang & 145 & 3,36 & Cumlaude & 4 \\
\hline 201208 & Mahasiswa05 & Perempuan & Karawang & 145 & 2,94 & Memuaskan & 4 \\
\hline 201209 & Mahasiswa06 & Perempuan & Luar Karawang & 145 & 3,42 & Sangat Memuaskan & 4 \\
\hline 201209 & Mahasiswa07 & Perempuan & Luar Karawang & 145 & 3,62 & Cumlaude & 4 \\
\hline 201210 & Mahasiswa08 & Laki-Laki & Luar Karawang & 145 & 3,29 & Sangat Memuaskan & 4 \\
\hline 201211 & Mahasiswa09 & Laki-Laki & Luar Karawang & 145 & 3,19 & Sangat Memuaskan & 4 \\
\hline 201212 & Mahasiswa10 & Laki-Laki & Karawang & 145 & 3 & Memuaskan & 4 \\
\hline 201213 & Mahasiswa11 & Perempuan & Luar Karawang & 145 & 2,93 & Memuaskan & 4 \\
\hline 201214 & Mahasiswa12 & Laki-Laki & Luar Karawang & 145 & 3,17 & Sangat Memuaskan & 4 \\
\hline 201215 & Mahasiswa13 & Laki-Laki & Karawang & 145 & 3,15 & Sangat Memuaskan & 4 \\
\hline 201216 & Mahasiswa14 & Laki-Laki & Karawang & 145 & 3,17 & Sangat Memuaskan & 4 \\
\hline
\end{tabular}

Pada tabel 7 diatas merupakan data mahasiswa angkatan 2012, 2013, 2014, 2015, dan 2016 yang sudah dilakukan pembersihan dengan tidak menggunakan baris data yang memiliki missing value.

\section{c. Construct Data}

Fase selanjutnya merupakan langkah untuk mempersiapkan data yang konstruktif yaitu membangun atribut turunan dari atribut yang ada. Pada tahapan ini melakukan penambahan satu buah atrubut baru yang dijadikan sebagai class target. atribut ini berisikan dua buah nilai yaitu "Tepat Waktu" dan "Terlambat".

Tabel 8. Atribut Baru

\begin{tabular}{c}
\hline Status Kelulusan \\
\hline Tepat Waktu \\
\hline Terlambat
\end{tabular}

Atribut tersebut didasari pada data lama studi dan tahun kelulusan mahasiswa yang dilihat pada nomor seri ijazah. Di mana mahasiswa yang mendapatkan class target atau dikategorikan sebagai mahasiswa yang lulus tepat waktu adalah mahasiswa yang menempuh stu di tidak lebih dari 4 tahun. Sehingga data yang telah ditambahkan atribut sebagai berikut.

Tabe1 9. Penambahan Atribut Baru Pada Data Mahasiswa STMIK Rosma Karawang

\begin{tabular}{|c|c|c|c|c|c|c|c|c|c|c|}
\hline 33 & Nomor Seri ljazah & NIM & Nama & Jenis Kelamin & Asal Daerah & Tanggal Lahir & SKS & IPK & Predikat & Lama Studi \\
\hline 34 & $20313 / 1$ & 200502 & Mahasiwa01 & Prempuan & Karawang & 27 September 1990 & 145 & 2,83 & Memuaska & 4 \\
\hline 35 & $20413 / 1$ & 200213 & Mahasiwa02 & Laki-Laki & Luar karawang & 22 Oktober 1991 & 145 & 3,19 & Sangat Me & 4 \\
\hline 36 & $20513 / 1$ & 200241 & Mahasiswa03 & Laki-Laki & Karawang & 13 Juni 1990 & 145 & 2,81 & Memuaska & 4 \\
\hline 37 & $20513 / 1$ & 200310 & mahasiswa04 & Laki-Laki & Karawang & 26 Februari 1995 & 145 & 2,97 & Memuaska & 4 \\
\hline 38 & $20613 / 1$ & 200835 & Mahasiswa05 & Laki-Laki & Karawang & 31 Desember 1993 & 145 & 2,98 & Memuaska & 4 \\
\hline 39 & $10013 / 1$ & 200401 & Mahasiswa06 & Prempuan & Karawang & 03 Maret 1992 & 145 & 2,79 & Memuaska & 3 \\
\hline 40 & $20013 / 1$ & 200501 & Mahasiswa07 & Laki-Laki & Karawang & 12 Juni 1993 & 145 & 2,80 & Memuaska & 5 \\
\hline 41 & $10013 / 1$ & 200512 & Mahasiswa08 & Laki-Laki & Karawang & 09 September 1984 & 145 & 3,57 & Sangat Me & 5 \\
\hline 42 & $40013 / 1$ & 200567 & Mahasiswa09 & Prempuan & Karawang & 16 Januar 1996 & 145 & 3,03 & Sangat Me & 5 \\
\hline 43 & $20013 / 1$ & 200767 & Mahasiswa10 & Laki-Laki & Karawang & 30 Maret 1996 & 145 & 3,63 & Sangat Me & 5 \\
\hline 44 & $90013 / 1$ & 200697 & Mahasiswa11 & Laki-Laki & Karawang & 19 September 1996 & 145 & 2,98 & Memuaska & 4 \\
\hline 45 & $20013 / 1$ & 200630 & Mahasiswa12 & Laki-Laki & Luar karawang & 10 Maret 1995 & 145 & 3,17 & Sangat Me & 4 \\
\hline 46 & $20213 / 1$ & 200532 & Mahasiswa13 & Laki-Laki & Luar karawang & 21 Juli 1993 & 145 & 3,18 & Sangat Me & 4 \\
\hline 47 & $20113 / 1$ & 200758 & Mahasiswa14 & Laki-Laki & Luar karawang & 16 Mei 1996 & 145 & 2,88 & Memuaska & 4 \\
\hline 48 & $20113 / 1$ & 200739 & Mahasiswa15 & Prempuan & Luar karawang & 20 Februan 1993 & 145 & 2,88 & Memuaska & 4 \\
\hline 49 & $20101 / 1$ & 200588 & Mahasiswa16 & Laki-Laki & Luar karawang & 10 Juli 1991 & 145 & 3,01 & Sangat Me & 4 \\
\hline
\end{tabular}

\section{d. Transformation}

Fase ini dilakukan untuk mengubah data maka digunakan transformasi data sehingga informasi terbaik dapat diambil dengan cara mengubah tipe data standar menjadi kategorikal sehingga dapat digunakan untuk klasifikasi teknik data minihg dengan algoritma C4.5. 
Pada data yang telah didapatkan terdapat beberapa atribut yang perlu diubah yaitu pada atribut jumlah SKS dan IPK. Jumlah SKS dibagi menjadi dua kategori yaitu jumlah SKS yang ditemuh kurang dari atau sama dengan 144 SKS $(\leq 144)$ dan jumlah sks yang lebih dari 144(>144). Pada atribut IPK juga dbagi menjadi dua kategori yaitu IPK yang dimiliki kurang atau sama dengan $3(\leq 3)$.

Tabel 10. Hasil Transformasi Atribut

\begin{tabular}{|c|c|c|c|c|c|c|c|c|}
\hline $\mathrm{N}_{0}$ & \begin{tabular}{|l|} 
Jumlah Sks \\
\end{tabular} & IPK & Nomor Seri Ijazah & NIM & Nama & \begin{tabular}{|l|} 
Jenis Kel \\
\end{tabular} & Asal Daerah & Tanggal Lahir \\
\hline 1 & SKS $>144$ & IPK $<=3$ & 20011 & 201201 & Mahasiswa01 & Prempuan & Karawang & 27 September 1990 \\
\hline 2 & SKS>144 & $\mathrm{IPK}>3$ & 20011 & 2012012 & Mahasiswa02 & Laki-Laki & Luar karawang & 22 Oktober 1991 \\
\hline 3 & SKS $>144$ & $\mathrm{IPK}>3$ & 20011 & 2012015 & Mahasiswa03 & Laki-Laki & Karawang & 13 Juni 1990 \\
\hline 4 & SKS>144 & $\mathrm{P} \times>3$ & 20011 & 2012014 & Mahasiswa04 & Laki-Laki & Karawang & 26 Februari 1995 \\
\hline 5 & SKS>144 & $\mathrm{IPK}>3$ & 20011 & 2020154 & Mahasiswa05 & Laki-Laki & Karawang & 31 Desember 1993 \\
\hline 6 & SKS $>144$ & IPK $<=3$ & 20011 & 2010123 & Mahasiswa06 & Prempuan & Karawang & 03 Maret 1992 \\
\hline 7 & SKS $>144$ & $\mathrm{IPK}>3$ & 20011 & 2010124 & Mahasiswa07 & Laki-Laki & Karawang & 12 Juni 1993 \\
\hline 8 & SKS $>144$ & $\mathrm{IPK}>3$ & 20011 & 2014002 & Mahasiswa08 & Laki-Laki & Karawang & 09 September 1984 \\
\hline 9 & SKS>144 & $\mathrm{IPK}>3$ & 20011 & 2014008 & Mahasiswa09 & Prempuan & Karawang & 16 Januari 1996 \\
\hline 10 & SKS $>144$ & $\mathrm{IPK}>3$ & 20011 & 2014009 & Mahasiswa10 & Laki-Laki & Karawang & 30 Maret 1996 \\
\hline 11 & SKS>144 & $\mathrm{IPK}<=3$ & 20011 & 20150019 & Mahasiswal1 & Laki-Laki & Karawang & 19 September 1996 \\
\hline 12 & SKS>144 & $\mathbb{P} K<=3$ & 20011 & 20150014 & Mahasiswa12 & Laki-Laki & Luar karawang & 10 Maret 1995 \\
\hline 13 & $S K S>144$ & $\mathrm{IPK}>3$ & 20011 & 20150026 & Mahasiswa13 & Laki-Laki & Luar karawang & 21 Juli 1993 \\
\hline 14 & SKS>144 & $\mathrm{IPK}>3$ & 20011 & 20150036 & Mahasiswa14 & Laki-Laki & Luar karawang & 16 Mei 1996 \\
\hline
\end{tabular}

\section{e. Format Data}

Fase terakhir pada tahapan preparation adalah format data. Pada fase ini dilakukannya produksi set data akhir yang siap digunakan untuk diolah menggunakan tools pemodelan data mining. Dataset yang akan digunakan untuk melakukan prediksi kelulusan yaitu sebagai berikut.

Tabel 11.Atribut Data Terpilih

\begin{tabular}{clll}
\hline No & \multicolumn{1}{c}{ Atribut } & \multicolumn{1}{c}{ Jenis } & \multicolumn{1}{c}{ Keterangan } \\
\hline $\mathbf{1}$ & Jenis Kelamin & Binominal & Jenis Kelamin Mahasiswa : Laki-Laki, Perempuan \\
\hline $\mathbf{2}$ & Asal Daerah & Binominal & Asal Daerah Mahasiswa : Karawang, Luar Karawang \\
\hline $\mathbf{3}$ & Jumlah SKS & Integer & Jumlah SKS yang telah ditempuh mahasiswa \\
\hline $\mathbf{4}$ & IPK & Real & Indeks Prestasi Kumulatif (IPK) mahasiswa \\
\hline $\mathbf{5}$ & Predikat & Polynominal & $\begin{array}{l}\text { Predikat Mahasiswa : Cumlaude, Sangat Memuaskan, } \\
\text { Memuaskan }\end{array}$ \\
\hline $\mathbf{6}$ & $\begin{array}{l}\text { Status } \\
\text { Kelulusan }\end{array}$ & binominal & Status Kelulusan : Tepat Waktu, Terlambat \\
\hline
\end{tabular}

\subsection{Modeling (Pemodelan)}

Prediksi kelulusan mahasiswa Teknik Informatika STMIK Rosma Karawang ini menggunakan metode decision tree. Metode decision tree ini dibangun menggunakan tools RapidMiner. Data yang digunakan sebanyak 127 datayang terdiri dari dua kelas yaitu tepat waktu dan terlambat untukmengetahi pola mahasiswa teknik informatika STMIK Rosma Karawang yang dapat menyelesaikan studinya dengan waktu lulus tepat atau terlambat berdasarkan variabel-variabel yang dianjurkan dengan menggunakan metode decision tree. Pada penelitian ini untuk mengukur validitas model klasifikasi digunakan cross validation. Cross validation merupakan salah satu metode untuk menentukan data training dan data testing dari keseluruhan data. Cross validation mengulang $\mathrm{n}$-kali untuk membagi himpunan data secara acak. Niali yang disarankan adalah 10 karena memiliki keakuratan yang lebih dalam ukuran estimasinya. Proses iterasi dilakukan sebanyak 10 kali sehingga dalam proses iterasu dihasilkan decision tree sebanyak 10. 


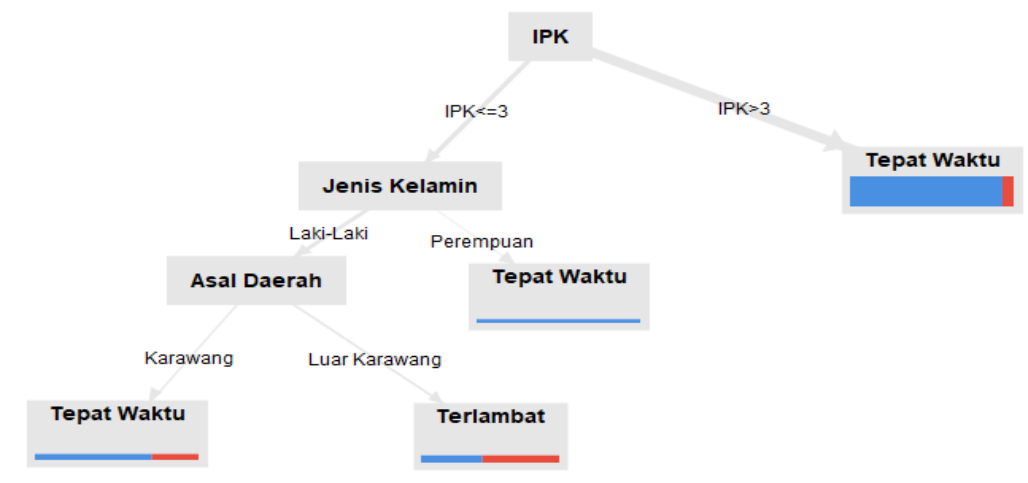

Gambar 2. Pohon Keputusan Klasifikasi Predikat Kelulusan

Pada gambar 2 terdapat hasil dari klasifikasi predikat kelulusan mahasiswa teknik informatika STMIK Rosma Karawang dengan metode decision tree. Dilihat pada pohon keputusan yang sudah terbentuk pola, maka dapat disimpulkan bahwa atribut yang memiliki pengaruh paling tinggi untuk menentukan klasifikasi predikat kelulusan mahasiswa teknik informatika STMIK Rosma Karawang adalah IPK. Hal ini ditunjukan dengan atribut IPK menempati simpul akar (root node).

\subsection{Evaluation (Evaluasi)}

Implementasi dari metode decition tree dengan menggunakan cross validation untuk mengukur validitas model dengan sebanyak 127 data mahasisa teknik informatika STMIK Rosma Karawang menghasilkan keberhasilan sebenyak 109 data. Klasifikasi predikat kelulusan mahasiswa dengan metode decizion tree ini didapatkan hasil klasifikasi yang disajikan dalam bentuk tabel confusion matrix. Confusion matrix memberikan informasi mengenai klasifikasi pada konsep data mining.

Tabel 12. Confusion Matrix

\begin{tabular}{llcc}
\hline & \multicolumn{3}{c}{ Actual } \\
\hline Prediction & & Tepat Waktu & Terlambat \\
\cline { 2 - 4 } & Tepat Waktu & $99(\mathrm{TP})$ & $10(\mathrm{FP})$ \\
\cline { 2 - 4 } & Terlambat & $8(\mathrm{FN})$ & $10(\mathrm{TN})$ \\
\hline
\end{tabular}

Berdasarkan tabel confusion matrix dengan algoritma decision tree, diketahui dari data yang berjumlah 127 data didapatkan 99 data tepat waktu benar diprediksi sebagai kelas tepat waktu, sementara 10 data tepat waktu diprediksi terlambat. sedangkan untuk kelas terlambat, 10 data terlambat benar diprediksi terlambat, sementara 8 data terlambat diprediksi tepat waktu.

Setelah diketahui hasil dari tabel confusion matrix, maka selanjtnya adalah mencari nilai dari accuracy, recall, precision dan AUC.

$$
\begin{gathered}
\text { Accuracy }=\frac{T P+T N}{T P+T N+F P+F N} \times 100 \%=\frac{99+10}{99+10+8+10} \times 100 \%=85,83 \% \\
\text { Recall }=\frac{T P}{T P+F N} \times 100 \%=\frac{99}{99+8} \times 100 \%=92,52 \% \\
\text { Precision }=\frac{T P}{T P+F P} \times 100 \%=\frac{99}{99+10} \times 100 \%=90,83 \%
\end{gathered}
$$




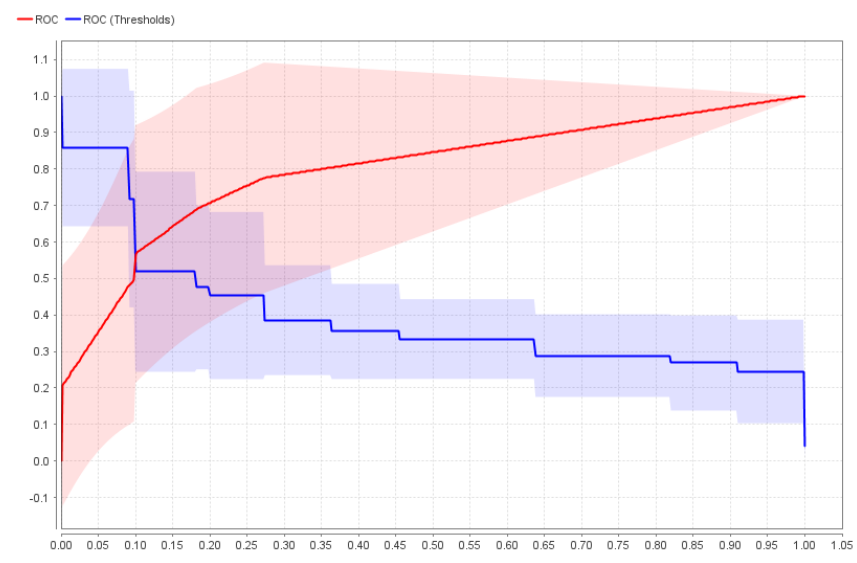

Gambar 3. Kurva ROC

Pada gambar 3 menunjukan bahwa dari model yang telah dibuat dan diuji menghasilkan bentuk kurva dengan nilai AUC sebesar 0,799 yang berarti akurasi dari prediksi adil atau sama.

\subsection{Deployment (Penyebaran)}

Tahap ini menjelaskan semua alur proses data mining yang telah dilakukan dalam memprediksi ketepatan kelulusan mahasiswa teknik informatika STMIK Rosma Karawang dan mengetahui kinerja dari metode decision tree dalam melakukan prediksi. Pada tahap ini terdapat tiga fase yaitu plan deployment, plan monitoring and maintenance, produce final report.

a. Plan Deployment

Rencana penyebaran dilakukan dengan membuat laporan kegitan selama penelitian. Laporan kegiatan berisikan hal-hal yang berikatan tentang penelitian selama berjalannya penelitian dimulai dari pengumpulan data akademik mahasiswa teknik informatika STMIK Rosma Karawang, pengolahan data, proses data yang terpilih dan pemodelan data menggunakan metode decision tree dan mencantumkan hasil klasifikasi yang telah didapat.

b. Plan Monitoring and Maintenance

Pemantauan dilakukan untuk memperhatikan setiap langkah pada tahapan proses data mining ketika melakukan prediksi. Hal tersebut dilakukan untuk mengetahui hasil evaluasi dari proses data mining dalam melakukan prediksi ketepatan kelulusan mahasisa teknik informatika STMIK Rosma Karawang, sehingga tidak ada satu tahapan yang terlewat. Hasil yang diproleh harus sesuai berdasarkan pada tahapan pemahaman bisnis yang telah dipaparkan sebelumnya yaitu melakukan prediksi tingkat kelulusan mahasiswa teknik informatika STMIK Rosma Karawang. Hasil prediksi yang dilakukan dengan menggunakan metode decision tree berdasarkan nilai accuracy, recall, prevision, dan AUC.

c. Produce Final Report

Fase ini membuat laporan dari semuakegiatan penelitian mengenai data mining dalam melakukan prediksi tingkat kelulusan mahasiswa yang telah dilakukan. Dimulai dengan pemahaman bisnis dan menjelaskan mengenai tujuan dari proses data mining yag dilakukan atau tujuan penelitian yaitu melakukan prediksi tingkat kelulusan mahasiswa teknik informatika STMK Rosma Karawang. Kemudian melakukan pengumpulan data akademik mahasiswa yang di mana data tersebut selanjutnya digunakan untuk mencari informasi mengenai atribut apa saja yang terkandung di dalam data tersebut. Setelah data diperoleh kemudian melakukan seleksi data untuk menentukan atribut terpilih yang kemudian akan di proses menggunakan teknik dan melakukan pembersihan data untuk menghilangkan record yang kosong untuk meningkatkan kualitas data. Selanjutnya data diubah sesuai dengan kebutuhan proses data mining. Setelah data siap digunakan, selanjutnya memilih metode decision tree sebagai teknik data mining yang akan digunakan. Selanjutnya membangun model dan menguji model yang dibuat. Setelah mengetahui hasilnya, selanjutnya mengevaluasi model yang telah digunakan. Laporan dibuat dalam bentuk presentasi dan proposal skripsi. 


\section{Kesimpulan}

Berdasarkan penelitian yang telah dilakukan dapat disimpulkan beberapa hal antara lain:

a. Penelitian ini melakukan klasifikasi predikat tingkat kelulusan mahasiswa program studi teknik informatika STMIK Rosma Karawang menggunakan metode desicion tree dengan menerapkan metodologi CRISP-DM. Penelitian ini diawali dengan pengamatan situasi yang terjadi di program studi teknik informatika STMIK Rosma Karawang. Kemudian melakukan pengumpulan data yang diperlukan, pembersihan data, dan transformasi data sebelum melakukan klasifikasi. Data yang digunakan untuk klasifikasi predikat tingkat kelulusan mahasiswa ini meliputi NIM, nama, jenis kelamin, asal daerah, tanggal lahir, jumlah sks, IPK, predikat, dan lama studi. Setelah data diperoleh sebnayk 146 data, selanjutnya membuat pemodelan dengan menggunakan cross validation untuk membagi data training dan data testing. Dataset yang digunakan untuk klasifikasi predikat kelulusan yaitu dataset mahasiswa angkata 2012, 2013, 2014, 2015, dan 2016 yang sudah lulus. Penggunaan metode desicion tree akan menghasilkan output berupaka pohon keputusan yang menampilan pola dari klasifikasi predikat kelulusan mahasiswa teknik informatika STMIK Rosma Krawarang. Hasil pengujian berupa tabel confusion matrix yang berisikan prediksi-prediksi benar dan salah. Dari prediksi tersebutlah yang akan digunakan untuk mencari nilai accurasy, recall, precision, dan AUC untuk mengevaluasi model prediksi.

b. Hasil semua pengujian dari pemodelan yang telah dibuat dengan pembagian data testing dan data training dengan menggunkan cross validation menghasilkan jumlah nilai true positif 99 , true negatif 10 , false ne gatif 8 , false positif 10 serta nilai accuracy sebesar $85,83 \%$, nilai recall sebesar 92,52\%, nilai precision sebesar 90,83\%, dan niali AUC sebesar 0,799.

\section{References}

Astuti, D., Iskandar, A. R., \& Febrianti, A. (2019). Penentuan Strategi Promosi Usaha Mikro Kecil Dan Menengah (UMKM) Menggunakan Metode CRISP-DM dengan Algoritma K-Means Clustering. Journal of Informatics, Information System, Software Engineering and Applications (INISTA), 1(2), 60-72. https://doi.org/10.20895/inista.v li2.71

Fadillah, A. P. (2015). Penerapan Metode CRISP-DM untuk Prediksi Kelulusan Studi Mahasiswa Menempuh Mata Kuliah (Studi Kasus Universitas XYZ). Jurnal Teknik Informatika Dan Sistem Informasi, 1(3), 260-270. https://doi.org/10.28932/jutisi.v1i3.406

Honesqi, H. D. (2017). Klasifikasi Data Mining Untuk Menentukan Tingkat Persetujuan Kartu Kredit. Jurnal Teknoif, 5(2), 57-62. https://doi.org/10.21063/jtif.2017.v5.2.57-62

Imaslihkah, S., Ratna, M., \& Ratnasari, V. (2013). Analisis regresi logistik ordinal terhadap faktor-faktor yang mempengaruhi predikat kelulusan mahasiswa S1 di ITS Surabaya. Jurnal Sains Dan Seni Pomits, 2(2), 177-182.

Luvia, Y. S., Hartama, D., Windarto, A. P., \& Solikhun. (2016). Penerapan Algoritma C4.5 Untuk Klasifikasi Predikat Keberhasilan Mahasiswa Di Amik Tunas Bangsa. Jurasik (Jurnal Riset Sistem Informasi Dan Teknik Informatika), l(1). https://doi.org/10.30645/jurasik.v1i1.12

Muhammad, Z., Rahmadhani, R., Rizqifaluthi, H., \& Yaqin, M. A. (2018). Process Mining Akademik Sekolah Menggunakan RapidMiner. Matics: Jurnal Ilmu Komputer Dan Teknologi Informasi, 10(2), 47-51. https://doi.org/10.18860/mat.v10i2.5745

Nasrullah, A. H. (2018). Penerapan Metode C4.5 untuk Klasifik asi Mahasiswa Berpotensi Drop Out. ILKOM Jurnal Ilmiah, 10(2), 244-250. https://doi.org/10.33096/ilkom.v10i2.300.244-250

Permata, E., Eddy Purnama, I. K., \& Hery Purnomo, M. (2012). Klasifikasi Jenis dan Fase Parasit Malaria Plasmodium Falciparum dan Plasmodium Vivax Dalam Sel Darah Merah Menggunakan Support Vector Machine. Setrum: Sistem Kendali-Tenaga-Elektronika-Telekomunikasi-Komputer, 1(2), 50. https://doi.org/10.36055/setrum.v1i2.475

Purnia, D. S., \& Warnilah, A. I. (2017). Implementasi Data Mining Pada Penjualan kacamata Dengan Menggunakan Algoritma Apriori. Indonesian Journal on Computer and Information Technology, 2(2), 31-39.

Rahayu, T. M., Ningsi, B. A., Isnurani, \& Arofah, I. (2021). KLASIFIKASI KETEPATAN WAKTU KELULUSAN MAHASISWA DENGAN METODE NAÏVE BAYES. Jurnal Media Bina Ilmiah, 15(10). http://ejurnal.binawakya.or.id/index.php/MBI

Rusdiana, \& Rosmiati, L. (2016). Aplikasi Berbasis Fuzzy C-Means Dalam Penentuan Predikat Kelulusan Mahasiswa. Jurnal Ilmiah Ilmu Komputer Fakultas ..., 2(2), 1-9. http://www.ejournal.fikomunasman.ac.id/index.php/jikom/article/view/78

Sartika, D., \& Sensuse, D. I. (2017). Perbandingan Algoritma Klasifikasi Naive Bayes, Nearest Neighbour, dan Decision Tree pada Studi Kasus Pengambilan Keputusan Pemilihan Pola Pakaian. Jurnal Teknik Informatika Dan Sistem 
Informasi, 1(2), 151-161.

Sitorus, D. R., Windarto, A. P., Hartama, D., \& Damanik, I. S. (2019). Penerapan Klasifikasi C4.5 Dalam Meningkatkan Sistem Pembelajaran Mahasiswa. KOMIK (Konferensi Nasional Teknologi Informasi Dan Komputer), 3(1), 593597. https://doi.org/10.30865/komik.v3i1.1665

Wajhillah, R., \& Yulianti, I. (2017). Penerapan Algoritma C4.5 Untuk Prediksi Penggunaan Jenis Kontrasepsi Berbasis Web. Klik - Kumpulan Jurnal Ilmu Komputer, 4(2), 160. https://doi.org/10.20527/klik.v4i2.98 